\title{
The making of Orpington
}

Citation for published version (APA):

Membery, Y. (2021). The making of Orpington: British political culture and the strange revival of liberalism, 1958-64. [Doctoral Thesis, Maastricht University]. ProefschriftMaken.

https://doi.org/10.26481/dis.20210517ym

Document status and date:

Published: 01/01/2021

DOI:

10.26481/dis.20210517ym

Document Version:

Publisher's PDF, also known as Version of record

\section{Please check the document version of this publication:}

- A submitted manuscript is the version of the article upon submission and before peer-review. There can be important differences between the submitted version and the official published version of record.

People interested in the research are advised to contact the author for the final version of the publication, or visit the DOI to the publisher's website.

- The final author version and the galley proof are versions of the publication after peer review.

- The final published version features the final layout of the paper including the volume, issue and page numbers.

Link to publication

\footnotetext{
General rights rights.

- You may freely distribute the URL identifying the publication in the public portal. please follow below link for the End User Agreement:

www.umlib.nl/taverne-license

Take down policy

If you believe that this document breaches copyright please contact us at:

repository@maastrichtuniversity.nl

providing details and we will investigate your claim.
}

Copyright and moral rights for the publications made accessible in the public portal are retained by the authors and/or other copyright owners and it is a condition of accessing publications that users recognise and abide by the legal requirements associated with these

- Users may download and print one copy of any publication from the public portal for the purpose of private study or research.

- You may not further distribute the material or use it for any profit-making activity or commercial gain

If the publication is distributed under the terms of Article $25 \mathrm{fa}$ of the Dutch Copyright Act, indicated by the "Taverne" license above, 


\section{Summary}

In March 1962 the Liberal Party won a highly symbolic by-election in Orpington, on the south-eastern fringe of Greater London, turning a near 15,000 vote Tory majority into a near 8,000 Liberal majority. Nearly 60 years on, it remains one of the most famous postwar British by-elections.

The enduring fascination with Orpington stems from it being the Liberal party's first big postwar win, its contemporary impact, and its significance for the wider history of British politics.

The by-election took place after a decade of Conservative government in a Britain on the cusp of profound socio-economic change: change reflected in the identity of two of the key players in the by-election, one British-Jewish (Peter Goldman) and one British-Indian (Pratap Chitnis), and the way in which the by-election was fought and covered by the media.

The result gave the Tories a serious jolt, helped pave the way for a government reshuffle - the so called 'Night of the Long Knives' in July 1962 in which the prime minister, Harold Macmillan, sacked a third of his cabinet - and briefly, to speculation in the press that the Liberals might even replace Labour, which had lost three general elections in a row, as Britain's main centre-left party.

However, despite tapping into the growing desire for change after the long years of Conservatism, the Liberals ultimately failed to alter the established party-political balance of power and capitalise on their by-election success in subsequent national elections. And many histories of postwar British politics have therefore paid 
comparatively little attention to Orpington or have largely looked at it with regard to its impact on the Conservative Party, and what it said about the Tory government.

My thesis challenges the widespread tendency amongst scholars to dismiss the Orpington election as a curious, but largely irrelevant moment in British postwar political history. At the same time, it seeks to explain the role of Orpington in the postwar Liberal revival, and explore the reasons why Orpington - for all the headlines in the next day's papers did not turn out to be a game-changer by-election, as initially seemed possible.

For that purpose, this thesis analyses in great empirical depth both the causes and the consequences of this 'shock to the system', while also looking in greater detail at aspects of the by-election that have moved to the centre of historiographical stage in recent years but have hitherto been largely ignored. This includes an emphasis on the role of race and gender in the British political culture of the era, and an assessment of the impact of changing media practices to the outcome.

In examining these themes, however, it aims to contribute to the broader historiographical project, exploring processes of continuity and change in British postwar political history by using the Orpington by-election as a means to illustrate deeper political, social, and cultural dynamics affecting the British political landscape.

The thesis aims to fill an empirical lacuna, juxtaposing new archival research into the byelection and the key players with never before recorded oral testimony. It has adopted a 'bottom-up' approach to the story where possible so as to provide a counterweight to a more conventional 'top-down' methodology that focuses on national party politics. For instance, it investigates how significant a contributory factor local Liberal activism also was to the result.

It explores how important the character of the two main candidates, the Liberal Eric Lubbock and the Conservatives' Peter Goldman, was to the outcome of the by-election, and asks how much of a hindrance Goldman's 'outsider' status, personality and Jewish 
background were to his chances of success. And it goes on to investigate one of the most controversial aspects of the by-election: the alleged anti-Semitism of both the local electorate and the Liberal campaign, and to what extent this impacted on the by-election result.

The thesis also looks at the role of tactical voting and opinion polls in the political contest and their significance to the Liberal win, as well as the way in which the print media and television news coverage interacted and fed off the other at Orpington, the first byelection where the result was covered live on television.

Furthermore it investigates the phenomenon of 'Orpington man' - the semi-mythical figure conjured up by the press after the shock by-election result to help explain this unlikely suburban revolt against the Tories - who was emblematic of the new, postwar upwardly-mobile man, and to a lesser extent woman (the coining of the term 'Orpington man' itself reflected the gender discourse and attitudes of the time), who did not feel the same class ties as his parents with either Labour or the Conservatives.

Last, it challenges another assertion found in the existing literature: that the reason there were no more 'Orpingtons' - subsequent Liberal by-election victories - in the more than eighteen months between Lubbock's victory in early 1962 and the general election of October 1964 (which resulted in a Labour victory) was down to the constituency's 'distinctiveness'.

The thesis concludes that for all the contemporary media excitement generated by Orpington, factors such as the British electoral system and the entrenched position of Labour and the Tories were always going to make a genuine Liberal breakthrough that much harder to achieve than seemed possible in the immediate aftermath of this famous by-election. 